This is the version of the article/chapter accepted for publication in Knowledge, Authority and Change in Islamic Societies: Studies in Honor of Dale F. Eickelman. Leiden: Brill, pp. 76-98

https://doi.org/10.1163/9789004443341_006

Accepted version downloaded from SOAS Research Online: http://eprints.soas.ac.uk/30625

Re-use is subject to the publisher's terms and conditions

\title{
Out of Sight in Morocco, or How to See the Jinn in the Modern-day Museum
}

\author{
Simon 0’Meara
}

\begin{abstract}
A picture held us captive. And we could not get outside it, for it lay in our language and language seemed to repeat it to us inexorably.

Ludwig Wittgenstein
\end{abstract}

\begin{abstract}
This essay explores Dale Eickelman's counter-intuitive insight that seeing in the modern-day museum is something that needs teaching. Exploring this pedagogical desideratum in the cultural context to which it pertains, namely, Islamic culture, the essay highlights the extent to which the modern-day museum strives for absolute visibility and shows how this aspiration sits awkwardly with Islamic culture, which is as much about invisibility as visibility. Responding to a recent challenge in visual anthropology that scholars should try to build a knowledge of their subject from a place of the quranic al-ghayb (the unknown, or invisible), the essay first grapples with the museological display of Islamic art from the place of the mostly invisible jinn. Second, it explores the extent to which the modern-day museum is embedded within a wider urban culture wed to a desire for total visibility and a certain type of pictoriality. This modern Western visuality, the essay suggests, is in many ways the opposite of Islamic visuality.
\end{abstract}

As anyone who has witnessed Dale Eickelman working in Morocco will tell you, he does not stand apart from his interlocutors, but fits right in. To the extent that it is possible, he closes the gap between observer and observed; not by imitation and costume, but empathy and the absence of all superiority. Remaining in plain sight, he yet disappears. Often he does so while pursuing his interests in aspects of the country that are themselves hidden from view, the cloak of power having rendered them invisible; for example, the operations of the king's bureaucracy, the Makhzan. Taking my cue from these interests and modus operandi of his, I propose to explore further the issue of invisibility by centring my paper about the disappearing jinn. I shall investigate the jinn's resistance to the space and representational system of the modern-day museum, which developed in Europe in the nineteenth century. Whereas Eickelman is an out of sight anthropologist to those with eyes to see, to the modern- 
day museum the jinn are not just out of sight but not even in the picture. How, then, to see the jinn there?

\section{How to see in museums}

In the President's Newsletter of December 2017 for the Tangier American Legation Institute for Moroccan Studies (TALIM), Eickelman talks of the Institute's ongoing mission to help protect the cultural heritage of Morocco. "One recent project," he relates, "has been to compile online lesson plans on 'How to See in Museums,' intended for intermediate and secondary school teachers in the region."1

At first glance, this teaching initiative seems plain wrong, for what could be more transparent to the eye than a museum, a primary purpose of which is to exhibit: to hold out objects to sight? ${ }^{2}$ Graeme Davison underscores this pivotal function of the modern-day museum when he takes the Panopticon, a planned but unbuilt eighteenth-century circular prison with a glass surveillance tower at its centre, and compares it to a precursor of the modern-day museum. The precursor in question is London's Great Exhibition of 1851, which was housed in transparency itself: the purpose-built Crystal Palace in Hyde Park. Davison remarks: "The Panopticon was designed so that everyone could be seen; the Crystal Palace was designed so that everyone could see." 3

1. Dale F. Eickelman, “TALIM President's Newsletter and Year-end Donation Appeal,” TALIM President's Newsletter, December 16, 2017, 2.

2 .Cf. Paul Basu and Sharon Macdonald, "Introduction: Experiments in Exhibition, Ethnography, Art, and Science," in Exhibition Experiments, ed. idem (Oxford: Blackwell, 2007), 2.

3. Graeme Davison, “Exhibitions,” Australian Cultural History 2 (1982/83): 7, as cited in Tony Bennett, The Birth of the Museum: History, Theory, Politics (London: Routledge, 1995), 65. On the "hand-in-glove" relationship between the world fairs of the nineteenth century and the modern museum, see Robert Rydell, "World Fairs and Museums," in A Companion to Museum Studies, ed. Sharon Macdonald (Oxford: Blackwell, 2006). Most recently, see 
How one negotiates the culturally coded space of the modern-day museum might need the mediating presence of a teacher, a possibility that Carol Duncan has exposed in her celebrated book on the art museum as a ritual site. ${ }^{4}$ The objects exhibited might also be deemed in need of pedagogic intervention to render them legible. ${ }^{5}$ But seeing in the museum is surely immediate, in need of no intervention, for the modern-day museum is predicated on sight.

To be sure, sight's dominion there has a history, and the museum has a history of techniques to facilitate this dominion. ${ }^{6}$ Additionally, recent developments in museum practices suggest sight's sovereignty may be giving way to sound and touch. ${ }^{7}$ Even so, because the museum's exhibitionary order overlaps with other modern exhibitionary orders, each reinforcing the other, sight is not going to be overtaken soon. ${ }^{8}$ Principal among these other orders is the shopping arcade and, especially, the department store, with its

Gudrun König, "Displaying Things: Perspectives from Cultural Anthropology," in On Display: Visual Politics, Material Culture, and Education, ed. Karin Priem and Kerstin te Heesen (Münster: Waxmann, 2016).

4. Carol Duncan, Civilizing Rituals: Inside Public Art Museums (Abingdon: Routledge, 1995). 5. See, e.g., Tracie Costantino, "Teacher as Mediator: A Teacher's Influence on Students' Experiences Visiting an Art Museum," The Journal of Aesthetic Education 42, no. 4 (2008). On legibility itself, see Tony Bennett, "Speaking to the Eyes: Museums, Legibility and the Social Order," in The Politics of Display: Museums, Science, Culture, ed. Sharon Macdonald (London: Routledge, 1998).

6. Tony Bennett, "Civic Seeing: Museums and the Organization of Vision," in A Companion to Museum Studies, ed. Sharon Macdonald (Oxford: Blackwell, 2006), 263-81.

7. Bennett, "Civic Seeing," 267; Sally Promey, "Foreword: Museums, Religion, and Notions of Modernity," in Religion in Museums: Global and Multidisciplinary Dimensions, ed. Gretchen Buggeln et al. (London: Bloomsbury, 2017), xxii.

8. Cf. Bennett, “Civic Seeing," 279. 
encyclopaedic range of products on display in carefully curated vitrines. ${ }^{9}$ As Gudrun König notes: "The association between the museum and the department store, trumpeted as a postmodern phenomenon, [is] a relationship with a long history."10

What is Eickelman talking about, then, when he speaks of learning how to see in the museum? To answer this question means asking if the sight the museum facilitates is culturally and historically specific. If it is, one might indeed need to learn how to see there if one were from a culture with only a limited history of museums; for example, the Arab Gulf States, with their rapid development of state-sponsored museums commencing in the 1970s. ${ }^{11}$

It is exactly this question of museum vision that is addressed in the present essay. It is my contention that a very specific type of sight is promoted in the modern-day museum that is at odds with, and even defies, quotidian ways of seeing in Islamic lands. As I shall contend, this sight, or "museological gaze" cannot register the peripheral, penumbral dimensions of seeing in Islamic lands. It cannot accommodate, I shall argue, a visuality sutured by worldly and otherworldly invisibility; by, for example, the jinn of the natural world and the evil eye (al-'ayn) of the supernatural world. For all its powers of penetration, and perhaps because of them, the museological gaze is insensitive to Islamic visuality, seeing through its shadows. As I shall demonstrate, it cannot account for a dimension of the Islamic cosmos that defines the realm of Islam writ large, namely, the invisible, divine world: the world of the unseen ('alam al-ghayb).

9. See, inter alia, Timothy Mitchell, Colonising Egypt (Cambridge: Cambridge University Press, 1988), 10-11; Nigel Whiteley, "High Art and the High Street: The 'Commerce-andCulture' Debate," in The Authority of the Consumer, ed. Russell Keat et al. (Abingdon: Routledge, 1994), 110-11; and Neil Cummings and Marysia Lewandowska, The Value of Things (Basel: Birkhaüser, 2000), passim.

10. König, "Displaying Things," 43.

11. See, e.g., Karen Exell, Modernity and the Museum in the Arabian Peninsula (London: Routledge, 2016). 
The argument is not that Islamic material culture on display in museums represents the evil eye, the jinn, and the unseen, and that this representation does not somehow register in the museological gaze. Rather, the argument is first that the visuality this material culture indexes is incompletely present in this gaze; and second that the index itself, the material culture, becomes present in a different way before this gaze. The representational system of the modern-day museum presents the index afresh: it represents it. For all that a museum might claim that it has on exhibition this or that never-seen-before artifact from this or that distant land, what one sees in the museum is the artifact's representation as a museum object, not the thing itself. As W.J.T. Mitchell notes regarding this distinction between an object and a thing: "Objects are the way things appear to a subject - that is, with a name, an identity, a gestalt or stereotypical template, a description, a use or function, a history, a science. Things, on the other hand [signal] the moment when the object becomes the Other, when the sardine can looks back, when the mute idol speaks, when the subject experiences the object as uncanny [...]."12 Museological representation is one of the ways that things become objects.

This museological representation has nothing to do with the meta-level questions of representation that the modern-day museum is perennially engaged with: how and why an artifact is selected for display and the choices that are made regarding, say, the lighting of that display. It has to do with something more fundamental: the transformation of the artifact by what Svetlana Alpers calls the museum effect, or "the tendency to isolate something from its world, to offer it up for attentive looking and thus to transform it into art like our own."13

12. W.J.T. Mitchell, What Do Pictures Want? The Lives and Loves of Images (Chicago: University of Chicago Press, 2005), 156-7.

13. Svetlana Alpers, "The Museum as a Way of Seeing," in Exhibiting Cultures: The Poetics and Politics of Museum Display, ed. Ivan Karp and Steven Lavine (Washington, D.C.: Smithsonian Institution Press, 1991), 27. Cf. "The act of collecting and exhibiting artifacts, of passing them across an exhibitionary threshold, is much more than an act of removal from some prior place, context, or condition. The object is not simply transported but 
The museum effect, Alpers argues, leads to this default condition: "It is to ourselves [...] that we are representing things in museums." 14

Does this museum effect matter? That depends on who we are. It might matter if we were, say, secular Europeans and wanted our audience to include more Muslim Europeans. ${ }^{15}$ Whoever we are, the effect could certainly benefit from unpacking; hence the timeliness, not to mention the correctness, of Eickelman's pedagogical initiative.

\section{Islamic visuality}

The term "visuality"' is first found in the work of Thomas Carlyle (d. 1881). ${ }^{16}$ It has sometimes been used by Islamic art historians, but without their giving a definition. ${ }^{17}$ In one

transformed." Donald Preziosi, "Art History and Museology: Rendering the Visible Legible," in A Companion to Museum Studies, ed. Sharon Macdonald (Oxford: Blackwell, 2006), 50 (italics as marked in the original).

14. Alpers, "The Museum as a Way of Seeing," 32.

15. Figures produced at the start of the twenty-first century regarding the interest of British Muslims in visiting British museums with permanent displays of Islamic material culture make for sombre reading. See Ian Heath, "The Representation of Islam in British Museums," 2 vols (PhD diss., University of Manchester, 2004), 2: 628-9. Although the author of these statistics subsequently published his (downloadable) dissertation, the book does not appear to include all the figures. Even so, see Ian Heath, The Representation of Islam in British Museums (Oxford: Archaeopress, 2007), 116-17.

16. Alexa Sand, "Visuality," Studies in Iconography 33 (2012): 89.

17. See, e.g., Christiane Gruber and Sune Haugbolle, "Introduction: Visual Culture in the Modern Middle East," in Visual Culture in the Modern Middle East: Rhetoric of the Image, ed. eadem (Bloomington: Indiana University Press, 2013), ix-xi, xxiii; and Laura Marks, "The Taming of the Haptic Space, from Málaga to Valencia to Florence", Muqarnas 32 (2015): 2537. I, too, use the term in the proceedings of a conference of 2009, and although I define it there, my understanding of visuality has developed since. See Simon O’Meara, "Muslim 
or two of these usages, it would seem to be a synonym of the term "visual culture," a parallel that would echo the usage of one of the foremost students and theorists of visuality, the aforementioned W.J.T. Mitchell. ${ }^{18}$ This leaves us, then, with the meaning of visual culture.

As explained by Mitchell, the study of visual culture is the equivalent of "ordinary language philosophy [in that] it looks at the strange things we do while looking, gazing, showing and showing off, such as hiding, dissembling, and refusing to look." 19 For Mitchell, this explanation means at least two things. First, that the study of visual culture, what is often called visual studies, ${ }^{20}$ entails, inter alia, "a meditation on blindness, the invisible, the unseen, the unseeable, and the overlooked." 21 Second, that this study cannot be limited to the "study of images or media, but extends to everyday practices of seeing and showing, especially those that we take to be immediate or unmediated." 22 Attempting to encapsulate this capacious field of study, Mitchell offers the chiastic aphorism that visual studies has for its object of study the social construction of the visual field and the visual construction of the social field. ${ }^{23}$ Visuality and visual culture are the two interchangeable names for this object of study; Islamic visuality and Islamic visual culture, the names for when the object pertains

Visuality and the Visibility of Paradise and the World," in Roads to Paradise: Eschatology and Concepts of the Hereafter in Islam, ed. Sebastian Günther and Todd Lawson, 2 vols (Leiden: Brill, 2017), 555-6.

18. W.J.T. Mitchell, “Showing Seeing: A Critique of Visual Culture," Journal of Visual Culture 1, no. 2 (2002): 166-7.

19. Mitchell, "Showing Seeing," 178.

20. See James Elkins, Visual Studies: A Skeptical Introduction (London: Intellect, 2003), 130.

21. Mitchell, "Showing Seeing," 170.

22. Ibid., 170.

23. Ibid., 171. By the second part of the aphorism, he means: "It is not just that we see the way we do because we are social animals, but also that our social arrangements take the forms they do because we are seeing animals." Ibid. 
to Islam. Because it names this object of study, there is no plural: there are not Islamic visualities, for example, which is not to say that the visuality in question cannot comprise a number of different, historical scopic regimes. For example, the visuality of the modern West is substantially informed by the scopic regime that Martin Jay calls "Cartesian perspectivalism" (because it derives from the quattrocento invention of linear perspective), but it is not reducible to this regime. ${ }^{24}$ An equivalent regime informing Islamic visuality would be the concept of modesty (hayā). ${ }^{25}$ Scopic regimes such as these act on the human organism's physiological drive to see: its scopic drive.

\section{Islamic visuality and the world of the unseen}

It is debatable whether the aforementioned evil eye constitutes an historical and thus mutable scopic regime of Islamic visuality or is a hard-wired part of it. That it might be the latter is because of the awesome power ascribed to it. The Prophet, for example, is alleged to have said that the evil eye was as strong as death itself, with the ability to outstrip divine destiny, or fate (qadar). ${ }^{26}$ This unearthly potency would suggest that the evil eye was

24. Martin Jay, "Scopic Regimes of Modernity," in Vision and Visuality, ed. Hal Foster (Seattle: Bay Press, 1988), passim.

25. See, e.g., Ze'ev Maghen, “See No Evil: Morality and Methodology in Ibn al-Qattan al-Fasi’s Ahkam al-nazar bi-hassat al-basar," Islamic Law and Society 14, no. 3 (2007): 342-90; and Simon O'Meara, Space and Muslim Urban Life: At the Limits of the Labyrinth of Fez (Abingdon: Routledge, 2007), 49-56.

26. E.g., "After natural causes, the evil eye is the greatest cause of death in my community" ( Akthar man yamutu min ummati ba'da qada'Allah wa qadarihi bi-l-anfus. Qala al-rawi: Ya'ni al-'ayn); and "Were anything to outstrip ( sabaqa) destiny, it would be the evil eye." Ibn Hajar al-'Asqalani, Fath al-bari fi sharh Sahih al-Bukhari, ed. 'Abd al-'Aziz b. 'Abd Allah b. Baz and Muhammad Fu’ad 'Abd al-Baqi, 15 vols (Cairo: Dar Misr li-l-Tiba'a, 2001), 10: 287 (kitab altibb, bab al-'ayn haqq, \#5740); and Abu al-Husayn b. al-Hajjaj Muslim, Sahih Muslim bi-sharh al-Nawawi, ed. 'Issam al-Sababti et al., 11 vols (Cairo: Dar al-Hadith, 1994), 7: 425 (kitab al- 
related to the world of the unseen, which in turn would suggest that it formed the immutable core of Islamic visuality; for as Shahab Ahmed has so persuasively argued, to be Muslim - to be Islamic - is to be in continuous engagement with the world of the unseen. ${ }^{27}$

As an aside, the following interpolation by a nineteenth-century Muslim translator of a French book on the "customs and mores of nations" is indicative of the place of the evil eye in Islamic visuality and suggestive of how this visuality is the opposite of modern Western visuality. In the French book, there is a sentence on the Middle Eastern belief in the evil eye, which reads as follows: "Throughout the Orient, the people fear what they call the evil eye." 28 The translator rendered the sentence as: "One of the beliefs ('aqa'id) of the Europeans is that the evil eye has no effect." 29 Having lived in Europe for five years, the Middle Eastern Muslim translator well knew that the Europeans recognised the evil eye as much as they recognised the jinn. Neither phenomenon registered in their sight.

Just as the evil eye's relationship to the world of the unseen is uncertain, so too is the jinn's relationship to that world. This is because although the Quran implies that with the coming of Islam no more can the jinn "steal the hearing" from heaven ( $Q$ 15:18, 72:8), it also says that they try to linger at heaven's boundary, straining to hear the "high assembly" $(Q$ $37: 8,72: 9)$. The occasional snatching of divine secrets would therefore seem to be a possibility still open to them, something the Quran appears to confirm (Q 26:221-2). ${ }^{30}$ This

salam, bab al-tibb wa al-marad wa al-ruqa, \#2188), respectively.

27. Shahab Ahmed, What is Islam? The Importance of Being Islamic (Princeton: Princeton University Press, 2015), 345-8.

28. Georges-Bernard Depping, Aperçu historique sur les mœurs et coutumes des nations (Paris: Aux bureaux de l'Encyclopédie Portative, 1826), 189.

29. Rifa'a Rafi' al-Tahtawi, Qala'id al-mafakhir fi gharib 'awa'id al-awa'il wa al-awakhir (Bulaq: Dar al-Tiba'a al-'Amira, 1833), 86.

30. Cf. Gerald Hawting, "Eavesdropping on the Heavenly Assembly and the Protection of the Revelation from Demonic Corruption," in Self-Referentiality in the Qur'ān, ed. Stefan Wild (Wiesbaden: Harrassowitz Verlag, 2006), 27. Note, however, the following encyclopaedia 
possibility is borne out in the popular imagination, where by and large the jinn retain their pre-Islamic status as beings capable of accessing the unseen world, and even being of it. ${ }^{31}$

For present purposes, whether or not the jinn belong to the world of the unseen is not of importance. What matters, rather, is the jinn's ability to appear and disappear from sight, to transform from seen to unseen beings; for this ability visually replicates what divides the seen from the unseen world. This ability is important, for the following reason.

In her book on the jinn, Amira El-Zein argues that these feared beings are intermediary beings, because they perpetually traverse the divide between the seen and the unseen worlds. This divide, she blankly asserts, is the basis of "the whole of Islam." 32 Given the signal importance of this divide in the thought of the aforementioned Shahab Ahmed, specifically as expressed in his posthumous publication What is Islam?, El-Zein's assertion is not unreasonable. ${ }^{33}$ Recently, another scholar, Amira Mittermaier, has effectively asked scholars to be like the jinn, challenging them to traverse the divide between the seen and the unseen worlds so as to read Islamic culture through the lens of the unseen (al-ghayb) and to write from its place. ${ }^{34}$ Al-ghayb, Mittermaier explains, should be understood not just as an ontological zone, but as a "site of epistemological reflection [because it] presupposes a particular attitude and relationship to the world, in which the very condition of not-knowing

entry in which that possibility is excluded: Jacqueline Chabbi, art. "Jinn," in Encyclopaedia of the Qur'ān, ed. Jane Dammen McAuliffe, 6 vols (Leiden: Brill, 2001-6), 3: 43, 46.

31. See, e.g., Constance Padwick, Notes on the Jinn and the Ghoul in the Peasant Mind of Lower Egypt, BSOAS 3, no. 3 (1924): 428. Much more recently, see Stefania Pandolfo, Knot of the Soul: Madness, Psychoanalysis, Islam (Chicago: Chicago University Press, 2018), 90-8, 269; and Amira Mittermaier, "The Unknown in the Egyptian Uprising: Towards an Anthropology of al-Ghayb," Contemporary Islam 13, no. 1 (2019): 21-2.

32. Amira El-Zein, Islam, Arabs, and Intelligent World of the Jinn (Syracuse: Syracuse University Press, 2009), xviii.

33. Ahmed, What is Islam?, 343-86, esp. $377 \mathrm{ff}$.

34. Mittermaier, "The Unknown in the Egyptian Uprising," 2, 14. 
is the foundation not only of faith but also of any knowledge." 35 As such, she provocatively concludes, scholars of the Islamic world should in turn try to build a knowledge of their subjects from a place of al-ghayb. ${ }^{36}$ With specific reference to the subject of Islamic anthropology, she says: "[Writing from a place of al-ghayb] means asking not simply how to do an anthropology of the invisible but also how al-ghayb can inflect anthropology." 37

In the section that follows below, I tentatively and very provisionally take up Mittermaier's challenge for the subject of Islamic art history, including its public face, the Islamic art museum, by engaging with the jinn as a proxy for al-ghayb.

\section{Dis/appearing jinn}

In the Quran, the Earth is effectively split into two domains, that of humankind and that of the jinn; numerous are the verses in which God simultaneously addresses both categories of sublunary created beings. ${ }^{38}$ The two domains are not, however, sealed off from each other, such that humans can, mostly inadvertently and unwillingly, enter the jinn's domain and the jinn can, less inadvertently and unwillingly, enter the humans'. ${ }^{39}$ With the exception of certain extraordinary individuals and the rarest of instances, the jinn are invisible to humans; they can, however, assume the form of an animal or even a human, and in that way appear and disappear before our very eyes. ${ }^{40}$ This means that Islamic visuality is not just

fundamentally informed by invisibility, in that, as per Shahab Ahmed, Islam is structured by the divide between the seen and unseen worlds of the Islamic cosmos; but more mundanely and equally quranically, Islamic visuality is riddled by dis/appearance. For

35. Ibid., 4.

36. Ibid., 13-14.

37. Ibid., 14.

38. Chabbi, "Jinn," 46.

39. Ibid., 44

40. The literature on this subject is vast, but for an introduction, see El-Zein, Intelligent World of the Jinn, 22-6, 89-120. 
phenomenologically speaking, the jinn are dis/appearance itself. "Appearance," writes Heidegger, "does not mean that something shows itself; rather it means that something which does not show itself announces itself through something that does show itself." 41

If in modern Western visuality, the phenomenon of dis/appearance is accounted for by the history of art - an art of appearance since the quattrocento until the rise of abstraction in the twentieth century ${ }^{42}$ - the same is not true in Islamic visuality. For Islamic art is only exceptionally about appearance; only rarely is it about optical naturalism. ${ }^{43}$ In Islamic

41. Martin Heidegger, Being and Time, trans. Joan Stambaugh (Albany: SUNY Press, 2010), 28.

42. See, e.g., the words of the expressionist painter Ernst Kirchner (d. 1938), for example: "A painter paints the appearance of things, not their objective correctness, in fact he creates new appearances of things." Cited in Norbert Wolf, Ernst Ludwig Kirchner 1880-1938: On the Edge of the Abyss of Time, trans. John William Gabriel (Cologne: Taschen, 2003), 14. See, too, the words of Merleau-Ponty regarding Cézanne (d. 1906): “[Cézanne condensed into visible objects] the vibration of appearances which is the cradle of things." Cited in Galen Johnson, "The Invisible and the Unrepresentable: Barnett Newman's Abstract Expressionism and the Aesthetics of Merleau-Ponty," Analecta Husserliana 75 (2002): 183. How appearance is understood, either as an optically registered, surface phenomenon that is seen solely in the presence of light or as something prototypical and more profound that is not seen solely in light, is a key distinction between modern (quattrocento and later) and medieval Western visuality. On this distinction, see Jack Greenstein, “On Alberti's 'Sign': Vision and Composition in Quattrocento Painting," The Art Bulletin 79, no. 4 (1997): 669-98. As John Berger notes regarding the former (modern) visuality: "All drawing is a shadow around light." Idem, The Shape of a Pocket (London: Bloomsbury, 2001), 145. In this same modern visuality, as Henri Bergson observed, there is no distinction between perception and the thing perceived. Idem, Matière et mémoire, 26 ${ }^{\text {th }}$ ed. (Paris: Félix Alcan, 1929), 200.

43. Notwithstanding the factual errors Hans Belting introduces into his analysis of Islamic theories of vision, specifically Ibn al-Haytham's (d. ca. 1040), and ignoring the predictably 
visuality, the phenomenon of dis/appearance is accounted for by the jinn. To display Islamic art as if it were, in Alpers's words, an "art like our own," namely, an optically naturalistic depiction of the appearing, physical world, and to do so without bringing into the picture the jinn, is to transform Islamic art, exactly as she says. Not only does the Islamic world comprise the jinn, but Islamic art rarely depicts the world.

\section{Glass boxes}

At the heart of the problem of the display of Islamic art in the modern-day museum is the fact that the museological gaze is part and parcel of modern Western visuality, not Islamic visuality, as I shall explain below. Stickers almost need to be affixed to the display cases to announce the fact, in the same way that stickers are often affixed to plate glass windows and doors to prevent people walking into them. Doing so would not constitute a

territorial and ungracious treatment meted out to it by certain Islamic art historians, in my view his counterposition of (predominantly anti-naturalistic) Islamic art and (naturalistic) quattrocento art is provocative and stimulating. See Hans Belting, Florence and Baghdad: Renaissance Art and Arab Science, trans. Deborah Lucas Schneider (Cambridge, Mass.: The Belknap Press of Harvard University Press, 2011), passim. Key aspects of Belting's book as they pertain to the present essay are contained in summary form in Hans Belting, "The Double Perspective: Arab Mathematics and Renaissance Art," Third Text 24, no. 5 (2010). Is A. Mark Smith correct when he asserts that Ibn al-Haytham's theory of vision was, pace Belting, "profoundly iconic"? Did not Joel Snyder get the matter correct decades ago when he said that retinal impressions were first understood iconically - as pictures, not as forms (sg. eidos) - in quattrocento Europe by Alberti (d. 1472), and that this understanding led to the invention of linear perspective or at least to its mathematical codification via the science of optics? See A. Mark Smith, "Review of Hans Belting, Florence and Baghdad: Renaissance Art and Arab Science (2011)," Journal of the Economic and Social History of the Orient 56 (2013): 525-6; and Joel Snyder, "Picturing Vision," Critical Inquiry 6, no. 3 (1980): 520, respectively. 
pointless joke, because the display cases contribute to the creation of the museological gaze. As noted by Khadija von Zinnenburg Carroll: "The glass between the artefact and the viewer is the [gaze's] epistemic membrane crystallized around an object." 44

The display cases might even be what create the gaze. As the same author writes elsewhere: "Built within the very architecture of the museum, vitrines are a structure of thinking. That structure frames any subject and object that enter the space but typically remains unanalyzed despite its effect on the formation of the ideas on display." 45 According to this argument, the display box acts like a lens, of the same order as a microscope, telescope, or camera. The lens establishes both the subject, who holds the lens, and the object, which is scrutinised through the lens.

The argument is not hyperbolic. Lewis Mumford, for example, considers that earlymodern European developments in glass-making, coupled with the widespread introduction of transparent glass these developments led to, gave birth to the modern scientific world. 46

44. Khadija von Zinnenburg Carroll, "The Inbetweenness of the Vitrine: Three Parerga of a Feather Headdress," in The Inbetweenness of Things: Materializing Mediation and Movement Between Worlds, ed. Paul Basu (London: Bloomsbury, 2017), 24.

45. Khadija von Zinnenburg Carroll, "Vitrinendenken: Vectors between Subject and Object," in The Challenge of the Object: Congress of the International Committee of the History of Art, ed. G. Ulrich Großmann and Petra Krutisch (Nuremberg: Verlag des Germanischen Nationalmuseums, 2013), 318.

46. "[Transparent] glass helped put the world in a frame: it made it possible to see certain elements of reality more clearly; and it focussed attention on a sharply defined field namely, that which was bounded by the frame. [...] [With the invention of the telescope and compound microscope] the naive conceptions of space that the ordinary man carried around were completely upset: one might say that these two inventions, in terms of the new perspective, extended the vanishing point toward infinity and increased almost infinitely the plane of the foreground from which those lines had their point of origin." Lewis Mumford, Technics and Civilization (London: Routledge \& Kegan Paul Ltd., 1934), 125-6. Cf. John 
He even lists the plate glass window alongside the microscope and telescope: one of the panoply of dioptric instruments invented in this period. 47 Others have interpreted woodcuts by Dürer (d. 1528) showing the use of just such dioptric instruments as an encapsulation of the scientific method itself, namely, the establishment of an object over which a subject stands in unblinking scrutiny (fig. 1).

\section{FIG. 1 HERE - full page, if possible}

Fig. 1: Woodcut illustrations of draughtsmen making linear perspective drawings of a vase and a reclining nude, from Albrecht Dürer (d. 1528), Underweysung der Messung (Instruction in Measurement) (Nüremburg, 1538). Page dimensions: 31.9 x $21.5 \mathrm{~cm}$. Courtesy: The Metropolitan Museum of Art, New York; gift of Felix M. Warburg, 1918; accession number 18.58.3; image in the public domain.

In the top woodcut, we see an artist using an eyepiece and a pane of transparent glass to create a linear perspective drawing of a vase. In the bottom woodcut, we see an artist using an eye-pointer and a pane of gridded but otherwise transparent glass to create a linear perspective drawing of a reclining nude, up whose parted thighs he stares. Regarding this bottom woodcut, inter alia, this interpretation has followed: the objectification of woman/nature by the male artist/scientist subject via his framed, instrumentalised, penetrative sight. ${ }^{48}$

Onians, European Art: A Neuroarthistory (New Haven: Yale University Press, 2016), 269. 47. Mumford, Technics and Civilization, 180-1 (fig. 2). Cf. Anne Friedberg, The Virtual Window: From Alberti to Microsoft (Cambridge, Mass.: The MIT Press, 2006), 110. For a more dispassionate account of the importance of early-modern developments in glassmaking for lens-based science, see A. Mark Smith, From Sight to Light: The Passage from Ancient to Modern Optics (Chicago: Chicago University Press, 2015), 325-6.

48. See especially, Lynda Nead, Female Nude: Art, Obscenity, and Sexuality (Abingdon: Routledge, 1992), 11; but also Allen Dunn, "The Pleasures of the Text: Volatile Visuality," Soundings: An Interdisciplinary Journal85, no. 3-4 (2002): 223; and Christy Anderson, “The 


\section{Linear perspective}

It is no coincidence that the glass-wielding artists in Dürer's two woodcuts are making linear perspective drawings. As Samuel Edgerton asserts in his book, The Mirror, the Window, and the Telescope: How Renaissance Linear Perspective Changed Our Vision of the Universe: "No rocket ship to the moon could ever have been invented, let alone be built and function, without the humble heritage of Renaissance linear perspective." 49 Although Edgerton's assertion sounds exaggerated, there is no shortage of similar assertions by other scholars that could replace it. ${ }^{50}$ For example, reworking a phrase coined by the philosopher of science Alexandre Koyré, Bryan Wootton refers to linear perspective's invention as the beginning of the "mathematization of the world," and thus the seed of the scientific revolution and origin of the modern world. ${ }^{51}$

Secrets of Vision in Renaissance England," in The Treatise on Perspective: Published and Unpublished, ed. Lyle Massey (Washington, D.C.: National Gallery of Art, 2003), 328-9. That the gridded frame contains transparent glass is specified in Anderson, "The Secrets of Vision," 329. Others have supposed the frame to be unglazed. See, e.g., Friedberg, The Virtual Window, 39. For an analysis of the historical development of these woodcuts, including the suggestion that the lower woodcut may not by Dürer, see Noam Andrews, "Albrecht Dürer's Personal Underweysung der Messung," Word \& Image 32, no. 4 (2016): 421-4.

49. Samuel Edgerton, The Mirror, the Window, and the Telescope: How Renaissance Linear Perspective Changed Our Vision of the Universe (Ithaca: Cornell University Press, 2009), 171.

50. E.g. "Renaissance artists' interest in perspective reflects the emergence at this time of modern science itself." Fred Kleiner, Gardner's Art Through the Ages: A Concise Western History, $4^{\text {th }}$ ed. (Boston: Cengage, 2007), 232.

51. Brian Wootton, The Invention of Science: A New History of the Scientific Revolution (New York: HarperCollins Publishers, 2015), 200. Karsten Harries makes a similar argument in idem, Infinity and Perspective (Cambridge, Mass.: The MIT Press, 2001), 14-16. 
In view of these assertions, we should take seriously Donald Preziosi's claim about the representational logic of the modern-day museum and its museological gaze. "Museums," he says, "put us in the picture, by teaching us how to appear picture-perfect." 52 The reason we should take it seriously is because our being in the picture is also the effect of linear perspective. The linear perspective painting is an extension of our own space: we are the subject of it, paradoxically constructed by it. In the words of Norman Bryson, linear perspective "is a personal construction, where the image recognises (more accurately, constructs) the viewer as a unitary subject, master of the prospect, unique possessor of the scene."53 In Preziosi's claim, the modern museum acts similarly, recomposing the fractured identity of the modern subject into a coherent picture. As he explains his claim:

[The museum is a place that enables the] modern social subject to be constituted as an anamorphosis of the bits and pieces of its own life and experience: a place from which to view those bits in such a way as to realign them in a (previously hidden or invisible) order, a "story" that makes a certain sense. [...] What the museum subject "sees" in this remarkable institutional space is a series of "mirrors" - possible ways in which it can construct or compose its life as one or another kind of centered unity or consistency which draws together in a decorous and telling order its sundry devices and desires. ${ }^{54}$

For all that the museum is about the objects it exhibits and archives, it is also all about me. As when viewing a linear perspective painting, in the museum I stand tangible, corporeal, and whole: possessing, and possessed by, a world of absolute visibility. ${ }^{55}$ This world is no world of the jinn, fleeting shadows of dis/appearance. As Christian Suhr has argued

52. Preziosi, "Art History and Museology," 53.

53. Norman Bryson, Tradition and Desire: From David to Delacroix (Cambridge: Cambridge University Press, 1984), 77 (italics as marked in the original).

54. Preziosi, "Art History and Museology," 53.

55. Cf. Norman Bryson, Vision and Painting: The Logic of the Gaze (New Haven: Yale University Press, 1983), 106. See also below. 
regarding the ultimate dioptric instrument of linear perspective construction, the camera, the jinn are outside of the picture. 56

Next, when I step outside the museum, not only do I find its world of absolute visibility reinforced by that of the department store and shopping arcade, as mentioned earlier, but also by that of the city as a whole. Exactly as Middle Eastern visitors to the world fairs of nineteenth-century Europe also experienced, there seems to be no outside to the exhibitionary order of the museum, because the city replicates it. ${ }^{77}$ The city, too, is arranged for my view, as a picture. The arrangement speaks of an urban practice whose origins date to trecento Italy, specifically Florence and its new satellite towns. As Marvin Trachtenberg says of this period of Florentine history in his award-winning book The Dominion of the Eye:

[T]recento painters shared with urban planners an intense engagement with the observer, with controlling the location and angle of vision and coordinating what is seen with where it is ideally seen from. This scopic desire led to the devising, respectively, of illusionistic and real spatial structures that fixed the ideal viewing point of both painting and monumental architecture, sometimes with extraordinary precision. Both media solicited the ambulatory viewer's immobility at a particular station, where the spatially structured and structuring pictorial and scenographic image was ideally to be sensorially produced and visually consumed. Whether this new experience was essentially "pictorial" or "architectural" is rather moot. ${ }^{58}$

Trachtenberg argues that the quattrocento invention of linear perspective in Florence was dependent on the trecento city's incipient early-modern visuality, and that the historical linkage between the two is provided by Brunelleschi's (d. 1446) lost perspectivedemonstration panels. Those panels are said to have represented two of the city's principal

56. Christian Suhr, "The Failed Image and the Possessed: Examples of Invisibility in Visual Anthropology and Islam," Journal of the Royal Anthropological Society21, no. 1 (2015): 109. On the direct connection between linear perspective painting and the camera, and thence photography, see Snyder, "Picturing Vision," passim.

57. Mitchell, Colonising Egypt, 5-12.

58. Marvin Trachtenberg, Dominion of the Eye: Urbanism, Art, and Power in Early Modern Florence (New York: Cambridge University Press, 1997) 181-4. 
monuments, the Palazzo Vecchio and Baptistery, both built or reworked according to the principles of trecento urbanism. As such, Trachtenberg argues, the panels tie trecento visuality to the quattrocento invention of linear perspective and further cement the bond between urbanism and painting initiated in the trecento. ${ }^{59}$

For Trachtenberg, the Panopticon-like visuality that the trecento gave rise to was deliberately produced and reproduced by the Florentine state as an instrument of authority. ${ }^{60}$ It is not hard to see its apotheosis in Baron Haussmann's redevelopment of Paris in the mid-nineteenth-century. ${ }^{61}$ Although the following eye-witness account by a Tunisian visitor to Haussmann's Paris refers to the experience of seeing a photographic panorama of the redeveloped city at the Paris world fair of 1889, not the city itself, the visitor's words are nonetheless revealing: "No different from reality [...] the observer sees himself at the centre (fi wasat) of the city, surrounded by its buildings, streets, and gardens." 62

Haussmann's Paris epitomised modernity. The replication of aspects of its precisely regimented space was thus not infrequently sought by Muslim states wishing to display their modern credentials. ${ }^{63}$ But the visuality this exported space belonged to was at a marked

59. Trachtenberg, Dominion of the Eye, 52-4; and more concisely in idem, "A Question of Origins," The Art Bulletin 84, no. 4 (2002).

60. Trachtenberg, Dominion of the Eye, 260.

61. For a history of the intervening centuries regarding the role of perspective in urban design, see Leonardo Benevelo, The European City, trans. Carl Ipsen (Oxford: Blackwell, 1993), 124-71.

62. Muhammad b. 'Uthman al-Sanusi, Istitla 'at al-barisiyya fi ma' rid 1889 (Tunis: n.a., 1891), 242.

63. See, e.g., Robert McChesney, "Architecture and Narrative: The Khwaja Abu Nasr Parsa Shrine. Part 2: Representing the Complex in Word and Image, 1696-1998," Muqarnas 19 (2002): 88; and Nezar AlSayyad, Cairo: Histories of a City (Cambridge, Mass.: The Belknap Press of Harvard University Press, 2011), 206-12. 
variance to the visuality it was imported into. This is because, for the most part, medieval and premodern Islamic urbanism eschews pictorially ordered public space. 64 On the occasions where something approaching pictorial public space is found in the Islamic context, as for example at the royal square of Safavid Isfahan, these represent the exception, not the rule. In the words of D. Fairchild Ruggles:

The opening up of space to allow long sight lines and sweeping views was more dramatic in the medieval Islamic context than a modern reader might initially realize. In the medieval environment, walls, doors, screens, and veils curtailed vision at every pass. Houses were not to be seen, except in a controlled manner by selected individuals and at select time; bodies were not to be seen, again except for a few individuals under controlled circumstances; and even in the supposedly public spaces of the city [...] there were few occasions when long-range views encompassing large spaces and many people were possible. [...] Vision was a tightly controlled experience; it had social power and as such was not available to more than a small group of people [...] ${ }^{65}$

Against this Islamic urban background, it is hardly surprising that the aforementioned Middle Eastern visitors to the world fairs of Europe found the cities there astonishing in their pictoriality, or intizam al-manzar (literally, organisation of the view). ${ }^{66}$ The reverse was no less true for the same period's European visitors to the Middle East. They found the Islamic medinas incomprehensible and impenetrable, and lamented their lack of a "point of view," or linear perspectival ordering principle. ${ }^{67}$ Only by heading for elevations beyond the perimeter walls could these Europeans see them as they wanted: as pictures. ${ }^{68}$

64. I address this subject in more detail in Simon O'Meara, "Haptic Vision: Making Surface Sense of Islamic Material Culture," in The Routledge Handbook of Sensory Archaeology, ed. Robin Skeates and Jo Day (London: Routledge, forthcoming 2019), 906-33.

65. D. Fairchild Ruggles, Gardens, Landscape, and Vision in the Palaces of Islamic Spain (University Park: Pennsylvania State University Press, 2000), 107.

66. Mitchell, Colonising Egypt, 12-13.

67. Ibid., 21-6.

68. Ibid., 24-6; 0’Meara, Space and Muslim Urban Life, 3. 


\section{Bigger boxes}

The gradual demise of the department store and shopping arcade in the twentieth-first century city has not ended the reciprocal relationship between the modern-day museum and the city. As public space in cities inexorably succumbs to what is called "brand urbanism," or the co-opting of this space by a corporate revisioning of it, so in many ways Apple Inc. leads the way with its iconic glass storefronts. First among these storefronts is the cubical one on Fifth Avenue, New York. But what is this structure, if not a museum vitrine writ large? It is a display case, albeit one wherein the item exhibited is not an Apple product but the Apple logo itself, the company's merchandise having been relocated to the store proper, below ground. 69

In the light of the connections this essay has drawn between the early modern and modern history of Western urbanism, the department store, and the museum, it might strike the reader as odd to learn that this Apple storefront in downtown New York, this "temple of consumerism," was originally mistaken by some Muslims as a copy of the Kaaba and a mockery of Islam. The problem was the black cladding temporarily used to protect the glass during the storefront's construction in late 2006. For with the cladding on, there was indeed a resemblance between the under-construction building and the Kaaba in Mecca. That resemblance led to an online outcry. ${ }^{70}$

I have written about this outcry elsewhere; for present purposes, what is interesting about the virtual storm the storefront occasioned is the fact that Apple's cube and Mecca's

69. For a finely nuanced discussion of what else this storefront is, including its connection to London's 1851 Great Exhibition at Crystal Palace, see Sarah Lookofsky, "Cults of Transparency: The Curtain Wall and the Shop Window in the Work of Dan Graham and Josephine Meckseper," in Sculpture and the Vitrine, ed. John Welchman (Farnham: Ashgate, 2016).

70. See Simon O'Meara, "The Kaaba of New York," in Taking Offense: Religion, Art, and Visual Culture in Plural Configurations, edited by Birgit Meyer et al. (Paderborn: Wilhelm Fink, 2018), 140-1. 
Kaaba belong to opposing visualities. Indeed, a case could be made that these visualities are diametrically opposite, such that perceiving the Kaaba in the storefront could hardly have been more wrong and yet also hardly more correct, because the two visualities form the two sides of the same coin. My reasoning is twofold:

1) As the point to which every Muslim is instructed to turn and face (Q 2:144), the Kaaba is where sight ends. Sight vanishes in the Kaaba. The same is true of linear perspective, the mathematical systemisation of optical sight that is involved in the visual organisation of early modern and modern Western urbanism, including New York and Apple's glass box therein. At the point called the vanishing point, which anchors this system, sight disappears.

2) As the point in Islamic creation myth from which the world is said to have been born, the Kaaba is not just the Islamic world's axis mundi, but also its matrix mundi. ${ }^{71}$ The same is true of the vanishing point: from this point the modern scientific world was born, exactly as noted by Courbet (d. 1877) in his version of the Creation myth, L'Origine du monde.72

71. See Simon O’Meara, "Mecca and other Cosmological Centres in the Sufi Universe," in Handbook of Sufi Studies. Vol. 2: Sufi Cosmology, ed. Christian Lange and Alexander Knysh (Leiden: Brill, forthcoming 2020).

72. As John Onians has recently shown, it is a mistake to view this painting as some kind of male locker-room joke, especially as Courbet made a number of "source" paintings, only one of which involved the female genitalia. See Onians, European Art, 311-12. Additionally, this particular source painting that shows a mostly disembodied "cosmic" vagina is preceded by some 150 years by a Tibetan Buddhist fresco of the same subject, except that in the fresco the vagina is totally disembodied and painted without regard for optical naturalism. See Ian Baker, The Dalai Lama's Secret Temple: Tantric Wall Paintings from Tibet(London: Thames and Hudson, 2000), 64-5. As Paola Uparella and Carlos Jáuregui have even more recently shown, Courbet's painting is also preceded by a European Enlightenment tradition of anatomical representations of the female genitalia and uterus. This tradition reduces the female body "to a pelvic body, with no arms, legs, or head," exactly as Courbet's painting does. See Paola Uparella and Carlos Jáuregui, “The Vagina and the Eye of Power (Essay on Genitalia 
Courbet's infamous painting is, of course, not itself the birthplace of this scientific world, but its title names it and its irreligiously frank, objectifying and, to some, phallocentric and exploitative viewpoint reveals its site-cum-sight (ur-sites constructing their sight). ${ }^{73}$ From this site, in this sight, with this viewpoint, nature is open to examination. Dürer's woodcut of the reclining nude does something similar, albeit more coyly: the draughtsman possesses the objectifying viewpoint, not the viewer, who, as an extension of the draughtsman, possesses it at one remove only. ${ }^{74}$ The viewpoint of Courbet's painting and the embedded viewpoint of Dürer's woodcut reveal the sight of the modern scientific world. The linear perspectival construction of both pictures speaks of this sight's site: the vanishing point outside of the view, which anchors the view, establishes the viewpoint, and owns the viewer who possesses this viewpoint. ${ }^{75}$ In Bryson's words once more: "[T] he vanishing point is the anchor of a

and Visual Sovereignty)," H-ART: Revista de historia, teoría y crítica de arte 3 (2018): 90. Courbet's painting is thus not idiosyncratic, but belongs to what Uparella and Jáuregui call a "gyneco-scopic regime." Ibid., 81. With thanks to Jonathan Bloom for alerting me to this article, and to John Gibson and Christian Luczanits for their help with the Tibetan fresco.

73. On ur-sites and sight, see Mark Wigley, The Architecture of Deconstruction: Derrida's Haunt (Cambridge, Mass.: The MIT Press, 1993), 61. Cf. the development of Wigley's argument in O'Meara, "The Kaaba of New York," 147-52. On the painting's phallocentric and exploitative viewpoint, see Uparella and Jáuregui, "The Vagina and the Eye of Power," $82 \mathrm{ff}$. 74. On the identification of the viewer with the draughtsman, see Bryan Wolf, "Confessions of a Closet Ekphrastic: Literature, Painting and Other Unnatural Relations," Yale Journal of Criticism 3 (1990): 196-7.

75. The paradoxical reversibility of the vanishing point and viewpoint is explained by Bryson as follows: "[The] vanishing point marks the installation within the painting of a principle of radical alterity, since its gaze returns that of the viewer as its own object: something is looking at my looking: a gaze whose position I can never occupy, and whose vista I can imagine only by reversing my own, by inverting the perspective before me, and by imagining my own gaze as the new, palindromic point of disappearance on the horizon." Bryson, Vision 
system which incarnates the viewer, renders him tangible and corporeal [as] a measurable, and above all a visible object in a world of absolute visibility." 76

"If we look closely," writes Baudrillard with reference to the thought of Hannah Arendt, "we see that the real world begins, in the modern age, with [...] the invention of an Archimedean point outside the world (on the basis of the invention of the telescope by Galileo and the discovery of modern mathematical calculation)." 77 What Baudrillard calls "the discovery of modern mathematical calculation" was made possible by the arrival into medieval Europe of the meta-sign zero. ${ }^{78}$ In linear perspectival constructions, a visual version of this meta-sign, visual zero, is the equivalent of what Baudrillard calls the "Archimedean point." 79 There is every reason to think that the Kaaba is this point's architectural equivalent: a tectonic zero, anchoring the symbolic order of Islam. ${ }^{80}$

and Painting, 107. On the basis of this paradox, it follows that "the epoch of the vanishing point [is] the transformation of the subject into object." Ibid. See also Bryson, Tradition and Desire, 220 n. 15.

76. Bryson, Vision and Painting, 106 (italics as marked in the original).

77. Jean Baudrillard, Why Hasn't Everything Already Disappeared?, trans. Chris Turner (London: Seagull Books, 2009), 10.

78. See, e.g., Robert Kaplan, The Nothing That Is: A Natural History of Zero (Oxford: Oxford University Press, 1999), 106 ff.; and Charles Seife, Zero: The Biography of a Dangerous Idea (London: Penguin Books, 2000), 78 ff. On zero as a meta-sign, or a "sign-about-signs outside it," see Brian Rotman, Signifying Nothing: The Semiotics of Zero (Stanford: Stanford University Press, 1987), 13.

79. Rotman, Signifying Nothing, 13-22.

80. This is a subject I pursue in my forthcoming monograph on the Kaaba. For present purposes, I refer the reader to Michel Chodkiewicz's description of the Kaaba as "a zero point in time [and] space," in idem, "Toward Reading the Futuhat Makkiya," in The Meccan Revelations: Ibn al- 'Arabi, ed. idem, trans. William Chittick et al., 2 vols (New York: Pir Press, 2002-4), 2: 23. 
These foregoing commonalities between the Kaaba and the Apple storefront are also what divide the visualities each represents. As noted earlier, the Kaaba belongs to a visuality sutured by divinely proclaimed invisibility, al-ghayb; the storefront, to a visuality that aspires to total transparency and absolute visibility. Both visualities can exist side by side in the same geographical location without that fact posing a logical contradiction; contemporary Mecca, with its high-rise hotels surrounding and dwarfing the Kaaba, is a case in point. In the modern-day museum, however, only the latter visuality obtains. Recognising that situation - teaching it - is the start of undoing it.

\section{Conclusion}

As desirable as it would be to conclude this essay knowing how to see the jinn in the modern-day museum, such a result was only ever very distantly on the horizon, the essay's title notwithstanding. The matter is beyond complex, and presumably for many if not most Muslims, also unnerving, with the goal unwelcome because frightening. The goal of the essay has realistically only ever been about establishing why it was necessary to create the conditions for the display of Islamic art so that the jinn could in principle be seen in the museum, so that the jinn and the unseen world, the alam al-ghayb, had a place there.

To be absolutely explicit, there is nothing wrong with the display of Islamic art in the museum as it currently stands. However, at a moment of academia when decolonising scholarship is high on the agenda, asking how better to display art that belongs to nonWestern visualities is a worthwhile question. Prescient as ever, Dale Eickelman has led us to this question. We now need some answers. With regard to Islamic art, my sense is that one answer will concern the fact that looking through windows onto carefully calibrated views, the principal activity of visitors in front of museum vitrines, was something only for the powerful and patriarchal in medieval and premodern Islamic urban culture. The open (but

unglazed) windows they looked through formed part of pictorially organised views. ${ }^{81}$ For

81. See Felix Arnold, Islamic Palace Architecture in the Western Mediterranean: A History (Oxford: Oxford University Press, 2017), 36-121. 
most other people, however, open windows at body height were rarely encountered, being generally screened. These screened windows did not allow looking through, but at best peering through, and were not part of pictorially organised views. As Fairchild Ruggles has noted, they additionally made one self-conscious about the act of looking itself: in confounding vision, they teased and drew attention to the eye. ${ }^{82}$ The shadowy fissures the screens threw across sight are reminiscent of the jinn lurking in the shadowlands between visibility and invisibility.

\section{BIBLIOGRAPHY - see separate document.}

$\mathrm{AF}$ (from the text I originally sent):

General queries.

1. I think there is a technical issue with the footnoting. The numbers appear as superscript but not the periods after the numbers. We will need to ask the copy editor to fix this. FIXED. DONE

2. As this is for a general audience as well as macro specialists it might be good to define terms. What is a "modern museum"? Also, always remember define and translate at least once any words that would be unfamiliar to general reader. DONE

This is really an exceptional contribution to the volume! (THANK YOU!) I think the application of the world of the unseen makes a great deal of sense. However, some of the first paragraphs are a bit unncessarily dense, especially the thesis paragrpah. " The argument, rather, is that the visuality this material culture indexes does not register in the gaze, and the index itself, the material culture, becomes re-presented in this gaze. For all that a museum might claim that it has on exhibition, of this or that never-before-exhibited object from this or that distant land, what one sees is the object's representation. One does not see the object." I am afraid you might lose the general reader and maybe even the specialist here. Simplifying this paragraph will help the reader move on to the rest of the essay which is really very good at explaining what you mean.

SOM: I hope this version is better and that you agree with me that I've corrected the flaws of the text in the ways you requested.

82. D. Fairchild Ruggles, "Making Vision Manifest: Frame, Screen, and View in Islamic Culture," in Sites Unseen: Landscape and Vision, edited by eadem and Dianne Harris (Pittsburgh: University of Pittsburgh Press, 2007), 155-6. 